\title{
Study on Innovative Paths of Ideological and Political Education for Contemporary College Students
}

\author{
Huimei Xiang
}

\section{Zhengzhou Vocational College of Industrial Safety, Xinzheng, 451192, China}

\begin{abstract}
In current context of global economic integration, ideological and political condition of contemporary college students is influenced from many aspects and their ideological activities are of gradually enhancing independence, differentiation and selectivity. Thus, we shall change traditional ways and methods of ideological and political education as soon as possible, carry actively out innovative paths of ideological and political education for contemporary college students starting from actual education condition, and then practically enhance and improve college students' ideological and political education, and finally strengthen educational effects and cultivate high-quality college students.
\end{abstract}

Key words: college students, ideological and political education, innovative paths

\section{Topic background}

Contemporary college students are the main force to realize Chinese dream, and their ideological and political quality is directly related to play of their roles in future socialist construction. However, with changes and development of international and domestic situations, college students' ideological and political education condition is not optimistic: it faces quite severe challenges, has a lot of weaknesses from some aspects, and hasn't formed a joint force of ideological and political education in colleges. In view of this, we shall take innovative paths of ideological and political education as soon as possible, improve educational effectiveness and pertinence, and thus enhance ideological and political quality of contemporary college students.

\section{Innovation necessity of contemporary college students' ideological and political education}

(1) Social economic environment changes substantially. Firstly, people-oriented concept enjoys popular support. Under current market economy condition, free and individualized development of each person is increasingly concerned. However, a large number of Chinese colleges have a misunderstanding of this and believe that students could give full play to their individual initiative regardless of school rules and regulations or others' and collective public interests. Such practice makes some college students have bad ideologies, such as decentralism, individualism and a lack of social moralities etc. Secondly, market economy has a profit-making feature, which results in worship of pragmatism and a lack of ambitious life ideals and faith of some college students. Besides, social income distribution and widening gap of wealth lead to subtle changes of some college students in terms of campus lifestyle and way of thinking etc, and social evils make college students doubt about the superiority of socialist system and governance by the Communist Party. Therefore, we shall establish firmly a sense of position, strengthen and promote smooth implementation of college students' ideological and political education;

(2) Coexistence of multicultural forms is required and is actually an objective requirement of innovation of ideological and political education for contemporary college students. Mainstream cultural development is positive and healthy in current China. Under the 
development trend of global economic integration, however, cultural integration trend becomes increasingly fast, and a variety of cultural products form a diversified cultural pattern. On the one hand, it could better meet and enrich college students' cultural life, and play a positive role in promoting the development of college students' ideological and political quality. However, on the other hand, college students' ideological quality is not completely mature, and they haven't completely established outlook on life, world outlook and values. As a result, they are very prone to influence of adverse cultural thoughts, their due political conviction and moral pursuit are eliminated to a certain degree, and thus they fall into a vulgar cultural atmosphere and have actually greatly reduced cultural life quality. Besides, the introduction and description of western cultures broaden college students' horizon, try ideologically to weaken traditional Chinese ethics and values, and make some college students worship things foreign and fawn on foreign countries. This requires more energy and time to be put into ideological and political education for college students, so as to guide them to establish positive and healthy psychological consciousness and form an enterprising spirit;

(3) Reform of higher education is deepening. It is the basic driving force of innovation of ideological and political education for contemporary college students. Chinese higher education enters a stage of rapid development, and shows more diversified schooling concepts while schooling scale is increasingly large. All of these lead to unpredictable changes of college students' ideological and political condition, and particularly some negative effects on their psychological development. China has annually increasing talent supply, which results in increasing employment pressure and more fierce campus learning and competition among college students. As time passes, they would have psychological burdens, pursue material gains, ignore improvement of spiritual accomplishment, and have quite severe decline of ideology and morality. Moreover, ages of college students become more hierarchical due to implementation of enrollment expansion policy in Chinese higher colleges, resulting in communication and exchange barriers, unharmonious factors, tense interpersonal relationships, and even unfair competitions for scholarships etc among some college students. Besides, today's college students are basically the only children of their families, and thus are generally weak in terms of psychological endurance and are prone to psychological barriers. Then, it becomes more important and urgent to carry out innovative ideological and political education in colleges;

(4) Information network transmission spreads. This is an important driving force of innovation of ideological and political education for contemporary college students. With today's changing science and technology, the era of knowledge economy has arrived, changes people's production mode and learning \& work mode significantly, and thus affects the content, object and scope of college students' ideological and political education. China has a constantly increasing number of internet users, among which college students are the main force. As a double-edged sword, network would not only bring huge social changes, but also cause unpredictable negative influence on traditional society. College students have more diversified and open access to information under network environment, while they are in a critical period with strong plasticity, bear increasing pressure and would easily have profound changes in ideological and political condition. When facing rich and colorful network world, they would easily be confused and lose due moral ideas. Meanwhile, network information transmission is bidirectional and highly free, while hostile foreign forces often confuse college 
students through network information. College students, who are in the critical period of life, can be easily affected by these western thoughts and thus have distorted or misplaced morality. In addition, college students' ability to distinguish between right and wrong is not strong enough, and thus they would easily be lost in complex and varying network world. Therefore, we shall carry out innovative ideological and political education with respect to diversified, individualized and complex ideology and way of thinking of contemporary college students in order to cope with various challenges;

(5) Ideological education function is weakened. Although some achievements have been made and rich experience has been accumulated in China's college ideological and political education, contemporary college students have extremely active and changeable thoughts and need normative guidance through scientific and effective ideological and political education. It should be said that this is an intrinsic requirement of innovation of ideological and political education for contemporary college students. This is because contemporary college students have generally more complex and changeable psychological performance, a backward stage of psychological maturity, and increasingly broad and decentralized concerns. This puts forward new requirements for college students' ideological and political education. According to current situation, college students' ideological and political education is obviously lagged behind with gradually lowering position and weakened functions, and thus its educational effects are seriously affected. Thus, colleges shall relocate ideological and political education from a strategic perspective, give full play to educational function of ideological and political education, improve educational pertinence, effectiveness and persuasion, stabilize ideological and political education teams, and truly give full play to orientation function of ideological and political education.

\section{Specific innovative paths of contemporary college students' ideological and political education}

Ideological and political education for contemporary college students shall contain innovative activities under guidance of principles, including benign interaction between people orientation and all-around development, organic combination of one-way instillation with solid interaction, dialectical unity of dominant education and diversified development, close integration of reasoning education with strict management, optimal improvement of inheritance for reference and development \& innovation etc. Based on these principles, ideological and political education for college students shall include such innovative paths, in order to better adapt to changes and development requirements of current situation, guide college students to establish firmly scientific and healthy ideological and political concepts and promote new vitality and vigor in such education.

(1) In terms of subjects of innovative education, subjects of college students' ideological and political education are directly related to educational effects. So, we shall practically strengthen cultivation of backbone teachers for ideological and political education. According to China's Opinions on Further Strengthening and Improvement of College Students' Ideological and Political Education by CPC Central Committee and State Council, college counselors and class advisers are backbone forces that carry out ideological and political education for college students, and so we shall improve their ideological quality and work competency and strive to establish a group of high-level counselors and class advisers with strong political sensitivity, fine professional ability, strict disciplines and correct attitude, so that they could play a greater 
role in ideological and political education work for college students. However, many of colleges in current China have not a sound group of counselors and class advisers, and so we shall do well from the following aspects. Firstly, we shall establish a scientific mode which combines part-time and full-time teachers, i.e. strengthen leadership practically, and increase treatment for counselors and class advisers from all aspects, set up a group of part-time and full-time counselors and class advisers, and bridge between them. Secondly, we shall carry out professional training for counselors and class advisers, such as allow them to be released from their regular work to study, give them more in-service training opportunities, and lead them to exercise, improve their knowledge structure, comprehensive quality, and work competency, and become more excellent. In addition, we shall also promote student counselors and class advisers to embark on a professional road, such as ensure quality of counselors and class advisers from the source, make clear their major job responsibilities, establish a pyramid group of ideological and political educators, and promote their vocational development;

(2) Main educational channels shall be of innovation, which is one of effective paths by which Chinese colleges improve the effectiveness of college students' ideological and political education. In course setting of Chinese colleges, ideological and political education is an important way of cultivating college students' outlook on life, world outlook and values, and reflects essential requirement of socialist colleges. However, some content is not recognized by the society or accepted by students. So, we shall carry out innovative main channels of ideological and political education to improve the effectiveness of theoretical classes of ideological and political education. Firstly, we shall change educational concepts, and particularly ideological and political education teachers shall master and carry out correct educational concepts, change mandatory education into instructive education, enhance college students' interest in ideological and political theoretical course, and improve their degree of recognition and effects of ideological and political education. Secondly, we shall strengthen discipline building, establish discipline position of ideological and political theoretical course, provide strong support for ideological and political education, further broaden discipline field, enrich discipline connotation, enhance discipline characteristics and promote effectively the development of this course. Thirdly, we shall improve qualities of ideological and political theoretical course teachers, such as their ideological quality and scientific research capability and level. Finally, we shall pay attention to innovation of teaching methods, improve pertinence and effectiveness of ideological and political education, link theory with practice, be concerned about various problems in students' practical life and learning, and make this course effective basis based on which students solve ideological and political problems;

(3) Educational concepts, carriers and platforms shall be of innovation. That is to say, ideological and political education for contemporary college students shall solve organically both ideological and practical problems. Ideological and political education for college students shall be based on actual situations, combine closely higher education condition with students' ideological changes, and be student-oriented to improve educational pertinence and appeal. Then, this requires us to do well in college student psychological health counseling and education, employment service guidance and subsidies work for poor students. Meanwhile, we shall also try to enrich carriers of ideological and political work, because college students' ideological and political education has many carriers and we shall make these carriers interact with and promote each other to further form an interactive and commonly 
progressing mechanism and create a good educational environment and atmosphere. Specifically, in ideological and political education, colleges shall try to educate students through practice, urge students to participate actively and initiatively in a variety of social practical activities, make them know about the importance and necessity of ideological and political quality through practical activities, enhance their moral consciousness, improve their moral sentiment, and gradually establish a relatively stable long-term social practice mechanism so that they could be noble talents through practice. Colleges shall also educate students through culture, and make students high-quality creative talents with comprehensive development in terms of morality, intelligence, physique and aesthetics. In addition, we shall also make full use of modern network information technology, and make it a new front of ideological and political education to better carry out full-scale education. Of course, we shall also establish an innovative ideological and political education platform, and give full play to the active role of college party and youth league organizations as well as student associations, in order to promote newer and more vertical development of ideological and political education for Chinese college students.

\section{References:}

[1] Chen Shuangxi. Reflections on Current Promotion of Innovative Ideological and Political Work [J]. Studies on Ideological and Political Work, 2011 (9): 45-47

[2] Gu Hailiang. The Ideological and Political Course System at the Tertiary Level: Development and Principal Features [J]. Teaching and Research, 2007 (2)

[3] Jian Qiandong. Taking Students as the Fundamental: the Value, Goal and Route of Current Ideological Political Education of Higher Learning Institutions [J]. Journal of Sichuan Normal University, 2007 (6)

[4] Yang Xiaohui. About Reforming College Students' Ideological and Political Education [J]. Theoretical Front in Higher Education, 2006 (12)

[5] Zheng Wentao. Ideological and Political Education for Contemporary College Students: Reality Reflection and Institutional Innovation [J]. Studies in Ideological Education, 2006 (6) 